\title{
Stress Induces the Danger-Associated Molecular Pattern HMGB-1 in the Hippocampus of Male Sprague Dawley Rats: A Priming Stimulus of Microglia and the NLRP3 Inflammasome
}

\author{
Michael D. Weber, ${ }^{1 *}$ Matthew G. Frank, ${ }^{1 *}$ Kevin J. Tracey, ${ }^{2}$ Linda R. Watkins, ${ }^{1}$ and Steven F. Maier ${ }^{1}$ \\ ${ }^{1}$ Department of Psychology and Neuroscience, Center for Neuroscience, University of Colorado, Boulder, Colorado 80309, and ${ }^{2}$ Laboratory of Biomedical \\ Science, Feinstein Institute for Medical Research, North Shore-LIJ Health System, Manhasset, New York 11030
}

\begin{abstract}
Exposure to acute and chronic stressors sensitizes the proinflammatory response of microglia to a subsequent immune challenge. However, the proximal signal by which stressors prime microglia remains unclear. Here, high mobility group box-1 (HMGB-1) protein was explored as a potential mediator of stress-induced microglial priming and whether HMGB-1 does so via the nucleotide-binding domain, leucine-rich repeat, pyrin domain containing protein 3 (NLRP3) inflammasome. Exposure to 100 inescapable tail shocks (ISs) increased HMGB-1 and NLRP3 protein in the hippocampus and led isolated microglia to release HMGB-1 ex vivo. To determine whether HMGB-1 signaling is necessary for stress-induced sensitization of microglia, the HMGB-1 antagonist BoxA was injected into the cisterna magna before IS. Hippocampal microglia were isolated $24 \mathrm{~h}$ later and stimulated with LPS ex vivo to probe for stress-induced sensitization of proinflammatory responses. Previous IS potentiated gene expression of NLRP3 and proinflammatory cytokines to LPS, that is, microglia were sensitized. Treatment with BoxA abolished this effect. To determine whether HMGB-1 is sufficient to prime microglia, IS was replaced with intracerebral administration of disulfide or fully reduced HMGB-1. Intracerebral disulfide HMGB-1 mimicked the effect of the stressor, because microglia isolated from HMGB-1-treated rats expressed exaggerated NLRP3 and proinflammatory cytokine expression after LPS treatment, whereas fully reduced HMGB-1 had no effect. The present results suggest that the CNS innate immune system can respond to an acute stressor as if it were cellular damage, thereby releasing the danger signal HMGB-1 in the brain to prime microglia by acting on the NLRP 3 inflammasome, in preparation for a later immune challenge.
\end{abstract}

Key words: DAMPS; HMGB-1; inflammasome; microglia; neuroinflammation; stress

\section{Introduction}

Exposure to stressors can lead to a proinflammatory environment within the brain, an outcome thought to be critical to the potential psychopathological effect of stressors (GadekMichalska et al., 2013, Fillman et al., 2014). Both acute and chronic stressors prime microglia (Frank et al., 2007) and amplify the neuroinflammatory response to a subsequent peripheral (Johnson et al., 2002, Wohleb et al., 2012) or central (de Pablos et al., 2006; Espinosa-Oliva et al., 2011) inflammatory challenge. The mechanism(s) by which stressors have neuroinflammatory effects is essentially unknown. However, blockade of the pattern

\footnotetext{
Received Aug. 25, 2014; revised Nov. 7, 2014; accepted Nov. 8, 2014

Author contributions: M.D.W., M.G.F., and S.F.M. designed research; M.D.W. and M.G.F. performed research; K.J.T., L.R.W., and S.F.M. contributed unpublished reagents/analytic tools; M.D.W. and M.G.F. analyzed data; M.D.W. wrote the paper.

This work is supported by National Institutes of Health Grant MH096224.

${ }^{*}$ M.D.W. and M.G.F. contributed equally to this work.

The authors declare no competing financial interests.

Correspondence should be addressed to Michael D. Weber, Department of Psychology and Neuroscience, Center for Neuroscience, University of Colorado Boulder, Boulder, C0 80309-0345. E-mail: webermd@colorado.edu.

DOI:10.1523/JNEUROSCI.3561-14.2015

Copyright $\odot 2015$ the authors $\quad 0270-6474 / 15 / 350316-09 \$ 15.00 / 0$
}

recognition receptors Toll-like receptor (TLR) 2 and TLR4 in the CNS during exposure to an acute stressor prevents the development of stress-induced exaggerated neuroinflammatory responses to later lipopolysaccharide (LPS; Weber et al., 2013). Thus, stressors must induce the release of an endogenous ligand within the CNS that signals via TLR2 and TLR4 to mediate neuroinflammatory sensitization produced by stressors. However, there are currently no known transmitters or modulators released in the brain by stressors that act at TLRs.

Although TLRs on peripheral immune cells were first thought to recognize only pathogen-associated molecular patterns, more recent findings suggest that a variety of conditions can lead to the release of endogenous molecules called alarmins or dangerassociated molecular patterns (DAMPs; Bianchi, 2007) that can also signal at TLRs (Park et al., 2004). The concept has developed that innate immune receptors discriminate between danger and non-danger rather than self and non-self (Matzinger, 2002).

High mobility group box-1 protein (HMGB-1) is perhaps the most studied alarmin. When released in the periphery, HMGB-1 interacts with TLR2, TLR4, and the receptor for advanced glycation end products (RAGE) in which it acts as both a chemotactic and proinflammatory mediator (van Zoelen et al., 2009). 
HMGB-1 plays a proinflammatory role in sterile injury and cellular stress in the periphery (Venereau et al., 2013) and is involved in a number of diseases (Kang et al., 2014).

Importantly, HMGB-1 has been reported to be present in the CNS and to mediate neuroinflammatory responses to ischemia and other injuries (Yang and Tracey, 2009). Here, we tested the novel idea that the CNS innate immune system responds to stress as "danger," thus releasing HMGB-1 in brain, and that HMGB-1 primes neuroinflammatory processes in the event of a later immune challenge. If so, this would provide a new perspective on the role of HMGB-1 and suggest that the meaning of danger as it applies to innate immunity needs to be expanded. In addition, a new mechanism by which stress acts on the brain would be indicated. We also explored the mechanism by which stress-induced HMGB-1 primes proinflammatory immune responses. HMGB-1 in the periphery has been demonstrated to induce the expression of the nucleotide-binding domain, leucine-rich repeat, pyrin domain containing protein 3 (NLRP3) inflammasome (Xiang et al., 2011). The NLRP3 inflammasome mediates maturation and secretion of IL-1 $\beta$ and is the only known inflammasome that requires a priming stimulus before it becomes active. Therefore, we also explored whether stress increases NLRP3 and whether stressinduced HMGB-1 modulates NLRP3 expression.

\section{Materials and Methods}

\section{Animals}

Male Sprague Dawley rats (60-90 d-old; Harlan Sprague Dawley) were pair housed with food and water available ad libitum. The colony was maintained at $25^{\circ} \mathrm{C}$ on a $12 \mathrm{~h}$ light/dark cycle (lights on at 7:00 A.M.). All rats were allowed 1 week of acclimatization to the colony rooms before experimentation. All experimental procedures were conducted in accordance with the University of Colorado Institutional Animal Care and Use Committee.

\section{Experimental design}

Experiment 1: effect of inescapable tail shock on hippocampal HMGB-1 and $N L R P 3$. Rats were killed immediately $(0 \mathrm{~h})$ or $24 \mathrm{~h}$ after inescapable tail shock (IS) exposure or served as home cage controls (HCCs). Hippocampal HMGB-1, NLRP3, and nuclear factor- $\kappa \mathrm{B}(\mathrm{NF}-\kappa \mathrm{B})$ protein levels were measured.

Experiment 2: effect of IS on hippocampal microglial release of HMGB-1. An increased level of HMGB-1 protein in hippocampal tissue does not necessarily indicate that HMGB-1 was secreted because it could have remained intracellular. Therefore, HMGB-1 release was measured from microglial cells of rats that had been exposed to IS or served as HCCs. Immediately after IS exposure $(0 \mathrm{~h})$, IS and HCC rats were killed, and hippocampal microglia were isolated. Equal numbers of microglia $\left(5 \times 10^{4} / 100 \mu \mathrm{l}\right)$ from each subject were incubated for $24 \mathrm{~h}$, HMGB-1 protein was measured in supernatants, and microglial cell viability was determined.

Experiment 3: effect of the HMGB-1 antagonist BoxA on IS-induced priming of microglia. Previous work has shown that exposure to IS primes microglia as assessed ex vivo in the sense that these microglia produce exaggerated inflammatory mediators in response to LPS (Frank et al., $2007)$. Rats were anesthetized with isoflurane ( $\sim 3 \mathrm{~min})$. The dorsal aspect of the skull was shaved and swabbed with $70 \% \mathrm{EtOH}$, and a 27 gauge needle, attached via polyethylene-50 tubing to a $25 \mu$ l Hamilton syringe, was inserted into the cisterna magna [intracisterna magna (ICM)]. To verify entry into the cisterna magna, $\sim 2 \mu \mathrm{l}$ of clear CSF was drawn and gently pushed back. Ten micrograms of BoxA (HMGBiotech; certified LPS free) were administered, suspended in $5 \mu$ l of pyrogen-free, sterile $\mathrm{H}_{2} \mathrm{O}$. An equal volume of sterile $\mathrm{H}_{2} \mathrm{O}$ was injected ICM for vehicle control rats. ICM administration was used to avoid implanting cannulae, which itself produces enduring neuroinflammation (Holguin et al., 2007). Rats were exposed to IS or served as HCCs immediately after full recovery from the brief anesthesia. Hippocampal microglia were isolated from IS and HCC rats $24 \mathrm{~h}$ after stressor termination. Microglia were suspended in media, and microglia concentration was determined by trypan blue exclusion. Microglia concentration was adjusted for each rat to yield an equal number of microglia $\left(1 \times 10^{4} / 100 \mu \mathrm{l}\right)$ for each in vitro condition across all rats. One hundred microliters were added to individual wells of a 96-well V-bottom plate. Cells were incubated with LPS $(0,0.1,1,10$, or $100 \mathrm{ng} / \mathrm{ml})$ for $4 \mathrm{~h}$ because we have determined previously that this concentration range and time of LPS exposure is optimal for microglial production of proinflammatory cytokines (Frank et al., 2006). Cells were washed in $1 \times$ PBS. Cells were lysed/homogenized and cDNA synthesis was performed according to the protocol of the manufacturer using SuperScript III CellsDirect cDNA Synthesis System (Invitrogen). Gene expression of proinflammatory cytokines was measured using real-time RT-PCR. Data from three cohorts were collected.

Experiment 4: effect of disulfide and fully reduced HMGB-1 on microglial proinflammatory response to LPS. Recent studies demonstrate that the redox state of HMGB-1 is a key determinant in the receptor interaction and immunological activity of HMGB-1. When cysteines in position C23, C45, and C106 are fully reduced (fully reduced HMGB-1), HMGB-1 functions as a chemotactic signaling protein but does not stimulate proinflammatory cytokines (Venereau et al., 2012). However, HMGB-1 functions as a proinflammatory mediator if a disulfide bond is formed between C23 and C45 under oxidizing conditions, whereas C106 remains in a reduced state (disulfide HMGB-1; Yang et al., 2012). Oxidation at all three cysteines abrogates both the chemotactic and proinflammatory properties of HMGB-1 (oxidized HMGB-1; Venereau et al., 2012). Thus, HMGB-1 orchestrates both chemotaxis and induction of inflammatory cytokines depending on the redox state of the protein. Therefore, both disulfide and fully reduced HMGB-1 were investigated. Oxidized HMGB-1 was omitted because it has not been associated with any in vivo function.

One microgram of disulfide or fully reduced HMGB-1 (HMGBiotech) was suspended in $10 \mu \mathrm{l}$ of sterile water and administered ICM. Twentyfour hours later, equal numbers of hippocampal microglia $\left(1 \times 10^{4}\right.$ cells/LPS condition) were incubated with LPS $(0,0.1,1,10$, or $100 \mathrm{ng} / \mathrm{ml})$ for $4 \mathrm{~h}$. The plate was washed in $1 \times \mathrm{PBS}$, cDNA synthesis performed, and gene expression of proinflammatory cytokines was measured using realtime RT-PCR.

\section{General procedures}

$I S$. Rats were placed in Plexiglas tubes $(23.4 \mathrm{~cm}$ length $\times 7 \mathrm{~cm}$ diameter) and exposed to $1001.6 \mathrm{~mA}, 5 \mathrm{~s}$ tail shocks with a variable intertrial interval (ITI) ranging from 30 to $90 \mathrm{~s}$ (average ITI, $60 \mathrm{~s}$ ). All IS treatments occurred between 9:00 A.M. and 11:00 A.M. IS rats were returned to their home cages immediately after termination of shock. HCC rats remained undisturbed in their home cages.

Tissue collection. Rats were injected with a lethal dose of sodium pentobarbital. During deep anesthesia, rats were transcardially perfused with ice-cold saline $(0.9 \%)$ for 3 min to remove peripheral immune cells from the CNS vasculature. Brains were rapidly extracted, placed on ice, and hippocampus dissected. For in vivo experiments, hippocampus was flash frozen in liquid nitrogen and stored at $-80^{\circ} \mathrm{C}$. For ex vivo experiments, microglia were isolated immediately (see below for procedure).

Western blot. Hippocampus was sonicated in a mixture containing extraction buffer (Invitrogen) and protease inhibitors (Sigma). Ice-cold tissue samples were centrifuged at $14,000 \mathrm{rpm}$ for $10 \mathrm{~min}$ at $4^{\circ} \mathrm{C}$. The supernatant was removed, and the protein concentration for each sample was quantified using the Bradford method. Samples were heated to $75^{\circ} \mathrm{C}$ for $10 \mathrm{~min}$ and loaded into a standard polyacrylamide Bis-Tris gel (Invitrogen). SDS-PAGE was performed in 3-(N-morpholino)propanesulfonic acid running buffer (Invitrogen) at $175 \mathrm{~V}$ for $1.25 \mathrm{~h}$. Protein was transferred onto a nitrocellulose membrane using the iblot dry transfer system (Invitrogen). The membrane was blocked with Odyssey blocking buffer (LI-COR Biosciences) for $1 \mathrm{~h}$ and incubated with a primary antibody in blocking buffer overnight at $4^{\circ} \mathrm{C}$. The following day, the membrane was washed in $1 \times$ PBS containing Tween $20(0.1 \%)$ and then incubated in blocking buffer containing either goat anti-rabbit or goat anti-mouse (LI-COR) IRDye $800 \mathrm{CW}$ secondary antibody at a concentration of 1:10,000 (LI-COR) for $1 \mathrm{~h}$ at room temperature. Protein expression was quantified using an Odyssey Infrared Imager (LI-COR) 
Table 1. Primer description and sequences

\begin{tabular}{|c|c|c|c|}
\hline \multirow[b]{2}{*}{ Gene } & \multicolumn{2}{|l|}{ Primer sequence $5^{\prime} \rightarrow 3^{\prime}$} & \multirow[b]{2}{*}{ Function } \\
\hline & Forward & Reverse & \\
\hline$\beta$-actin & TTCCTTCCTGGGTATGGAAT & GAGGAGCAATGATCTTGATC & $\begin{array}{l}\text { Cytoskeletal protein } \\
\text { (housekeeping } \\
\text { gene) }\end{array}$ \\
\hline CD163 & TCATTCAACCCTCACTGCAC & CTTGAGGAAACTGTAAGCCG & $\begin{array}{l}\text { Macrophage antigen } \\
\text { not expressed by } \\
\text { microglia }\end{array}$ \\
\hline GFAP & AGATCCGAGAAACCAGCCTG & ССTTAATGACCTCGCCATCC & Astrocyte antigen \\
\hline IL-1 $\beta$ & CCTTGTGCAAGTGTCTGAAG & GGGCTTGGAAGCAATCCTTA & $\begin{array}{l}\text { Proinflammatory } \\
\text { cytokine }\end{array}$ \\
\hline IL-6 & AGAAAAGAGTTGTGCAATGGCA & GGCAAATTTCCTGGTTATATCC & $\begin{array}{l}\text { Proinflammatory } \\
\text { cytokine }\end{array}$ \\
\hline MHCII & AGCACTGGGAGTTTGAAGAG & AAGCCATCACCTCCTGGTAT & $\begin{array}{r}\text { Microglia/macro- } \\
\text { phage antigen }\end{array}$ \\
\hline $\mid \kappa \mathrm{B} \alpha$ & САCCAACTACAACGGCCACA & GCTCCTGAGCGTTGACATCA & $\begin{array}{l}\text { Induced by NF- } \kappa \text { B to } \\
\text { inhibit NF- } \kappa B \\
\text { function }\end{array}$ \\
\hline $\operatorname{TNF} \alpha$ & CAAGGAGGAGAAGTTCCCA & TTGGTGGTTTGCTACGACG & $\begin{array}{l}\text { Proinflammatory } \\
\text { cytokine }\end{array}$ \\
\hline
\end{tabular}

and expressed as a ratio to their housekeeping protein. HMGB-1 protein was measured in cell culture supernatants using identical Western conditions except that measurement of GAPDH was excluded. Primary antibodies included rabbit anti-rat HMGB-1 monoclonal antibody (1: 4000; Abcam), rabbit anti-rat NLRP3 monoclonal antibody (1:1000; Abcam), mouse anti-rat active NF- $\kappa$ B monoclonal antibody (1:1000; Millipore), rabbit anti-rat GAPDH monoclonal antibody (1:200,000 Abcam), and mouse anti-rat $\beta$-actin (1:200,000; Sigma-Aldrich).

Microglia isolation and culture conditions. Hippocampal microglia were isolated using a Percoll density gradient as described previously (Frank et al., 2006). We have shown previously (Frank et al., 2006) that this microglia isolation procedure yields highly pure (>95\%) microglia [ionized calcium-binding adapter molecule 1-positive/major histocompatibility complex II (MHCII)-positive/cluster of differentiation 163 (CD163)-negative/glial fibrillary acidic protein (GFAP)-negative]. Immunophenotype and purity of microglia was assessed and verified using real-time RT-PCR of MHCII, CD163, and GFAP. Microglia were routinely found to be MHCII-positive/CD163-negative/GFAP-negative (data not shown). Microglia were cultured in $100 \mu$ l of DMEM plus $10 \%$ FBS, and microglia concentration was determined by trypan blue exclusion. Microglia were plated in individual wells of a 96 -well V-bottom plate and incubated at $37^{\circ} \mathrm{C}, 5 \% \mathrm{CO}_{2}$ under the experimental conditions described above.

MTT assay of cell viability. Microglia were incubated with $12 \mathrm{mM}$ MTT (Life Technologies) at $37^{\circ} \mathrm{C}$ for $4 \mathrm{~h}$. Fifty microliters of DMSO were added to each well and incubated at $37^{\circ} \mathrm{C}$ for $10 \mathrm{~min}$. Absorbance was measured at $540 \mathrm{~nm}$, and cell viability was determined according to the protocol of the manufacturer (Life Technologies).

Real-time RT-PCR measurement of gene expression. A detailed description of the PCR amplification protocol has been published previously (Frank et al., 2006). cDNA sequences were obtained from GenBank at the National Center for Biotechnology Information (NCBI; www.ncbi.nlm. nih.gov). Primer sequences were designed using the Eurofins MWG Operon Oligo Analysis and Plotting Tool (http://www.operon.com/ technical/toolkit.aspx) and tested for sequence specificity using the Basic Local Alignment Search Tool at the NCBI (Altschul et al., 1997). Primers were obtained from Invitrogen. Primer specificity was verified by melt curve analysis. All primers were designed to span exon/exon boundaries and thus exclude amplification of genomic DNA (for primer description and sequences, see Table 1). PCR amplification of cDNA was performed using the Quantitect SYBR Green PCR kit (Qiagen). Formation of PCR product was monitored in real time using the MyiQ Single-Color RealTime PCR Detection System (Bio-Rad). Relative gene expression was determined by taking the expression ratio of the gene of interest to $\beta$-actin.
Statistical analysis and data presentation. All data are presented as mean \pm standard error of the mean (SEM). Statistical analysis consisted of Student's $t$ test or ANOVA using Prism 5 (GraphPad Software). Omnibus $F$ values are reported for each ANOVA and serve as a criterion for post hoc analysis (Newman-Keuls test). Threshold for statistical significance was set at $\alpha=0.05$.

\section{Results}

\section{Stress exposure induces hippocampal microglia to release HMGB-1}

The first goal was to determine whether HMGB-1 is increased in the hippocampus after stress exposure. The hippocampus was targeted because it is an area that shows robust IS-induced priming of neuroinflammatory processes in vivo (Johnson et al., 2002) and ex vivo (Frank et al., 2007) and yields a sufficient number of microglia to perform ex vivo experiments. There was a significant interaction between IS vs HCC and $0 \mathrm{vs} 24 \mathrm{~h}$ post-stress treatment $\left(F_{(1,23)}=11.97, p<0.01\right)$. Post hoc analysis revealed that HMGB-1 protein was significantly increased $0 \mathrm{~h}$ after IS compared with HCC rats $(p<0.001)$ and remained significantly elevated $24 \mathrm{~h}$ after IS compared with HCC rats $(p<0.01$; Fig. $1 A)$. This result provided initial evidence that HMGB-1 is modulated by stress. However, HMGB-1 is located primarily in the nucleus and is not considered to be an alarmin unless released into the extracellular space (Lotze and Tracey, 2005). Simply measuring HMGB-1 protein or mRNA in brain tissue cannot indicate whether the increased HMGB-1 was secreted. Microglia were targeted for such an analysis because they are the predominant innate immune cell in the brain. To measure released HMGB-1, rats were exposed to IS or served as HCCs, and hippocampal microglia were isolated immediately after stress treatment. HMGB-1 was measured in the supernatant after a $24 \mathrm{~h}$ incubation period, which allowed sufficient time for detectable levels of protein to accumulate. Previous exposure to IS led microglia to release an increased amount of HMGB-1 compared with microglia isolated from HCC rats $\left(t_{(13)}=5.429, p<0.0001\right.$; Fig. $1 B)$. Although we have demonstrated previously that the isolation procedure does not change the immunophenotype of microglia (Frank et al., 2006), the presence of HMGB-1 in the supernatant of HCC microglia suggests that the culture conditions contribute to the release of HMBG-1 ex vivo, and this should be noted. Nonetheless, HMGB-1 was significantly elevated in the supernatant from microglia exposed to IS. Of course, the IS-induced increase of HMGB-1 could be attributable to cell death. Therefore, an MTT assay was performed to measure cell viability of microglia after the supernatant was removed. We found no difference in cell viability $(t=0.933, p=0.93$; Fig. $1 C)$, demonstrating that the elevated levels of HMGB-1 are likely not attributable to microglia death, thus suggesting that IS-induced active release of HMGB-1 from microglia into supernatant.

\section{Stress induces NLRP3 and NF- $\kappa$ B protein in hippocampus}

Next, we examined NLRP3 and upstream signaling markers in hippocampal tissue after stress exposure. NLRP3 protein was significantly increased 0 and $24 \mathrm{~h}\left(F_{(2,23)}=3.907, p<0.05\right.$; Fig. $\left.2 B\right)$ after stress treatment compared with HCC rats. However, NLRP3 mRNA was not significantly changed by stress exposure (Fig. 2A). NLRP3 is induced by the transcription factor NF- $\kappa$ B, and so we measured NF- $\kappa \mathrm{B}$ as an upstream NLRP3 marker (Bauernfeind et al., 2009). We used an antibody that binds to an epitope of the p65 subunit that is exposed after degradation of the inhibitory chain nuclear factor of kappa light polypeptide gene enhancer in B-cells inhibitor, alpha $(\mathrm{I} \kappa \mathrm{B} \alpha)$, thus representing active NF- $\kappa \mathrm{B}$. Stress 


\section{A}

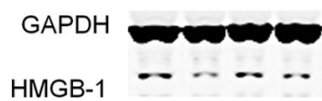

IS HCC IS HCC

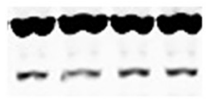

IS $\mathrm{HCC}$ IS $\mathrm{HCC}$
B

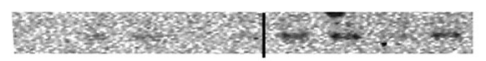

HCC

IS
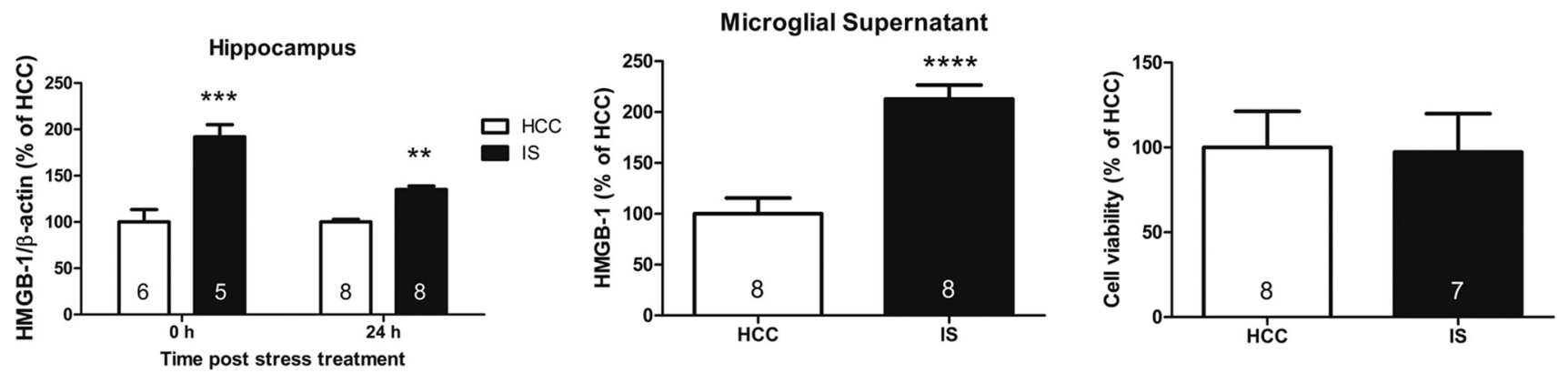

Figure 1. Effect of IS on HMGB-1. A, HMGB-1 is increased in the hippocampus 0 and $24 \mathrm{~h}$ after IS compared with HCCS. B, Hippocampal microglia were isolated $0 \mathrm{~h}$ after IS or from HCCs and incubated for $24 \mathrm{~h}$. HMGB-1 is increased in the supernatant of microglia isolated from rats exposed to IS. C, There was no difference in cell viability between microglia isolated from IS or HCC treatment. The graphs show mean and SEM. Sample sizes are represented in the bar graph. Representative Western blots are shown above each graph when appropriate. ${ }^{* *} p<0.01$, ${ }^{* * *} p<0.001$ versus the HCC group.

A

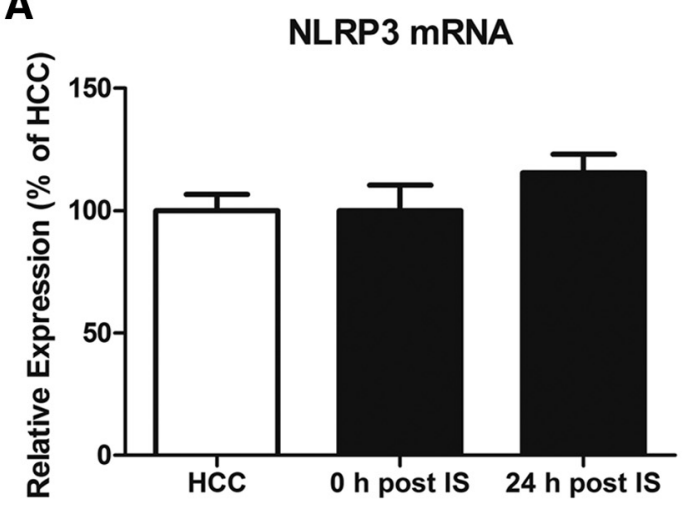

C
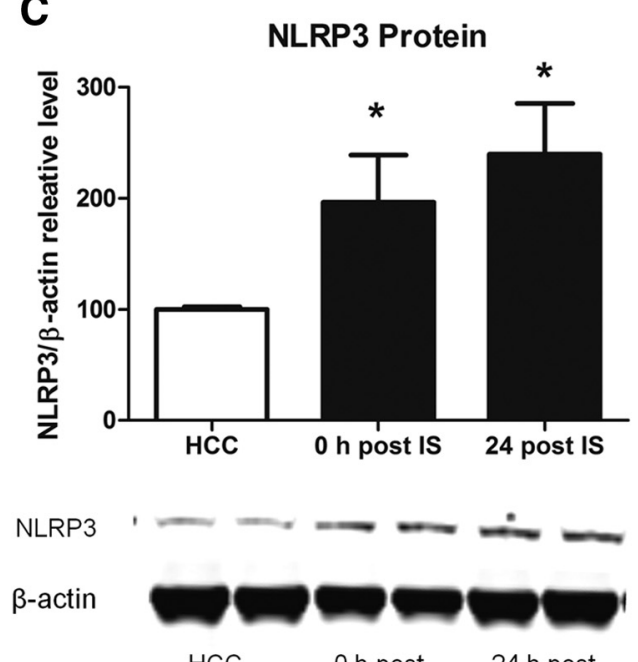

B

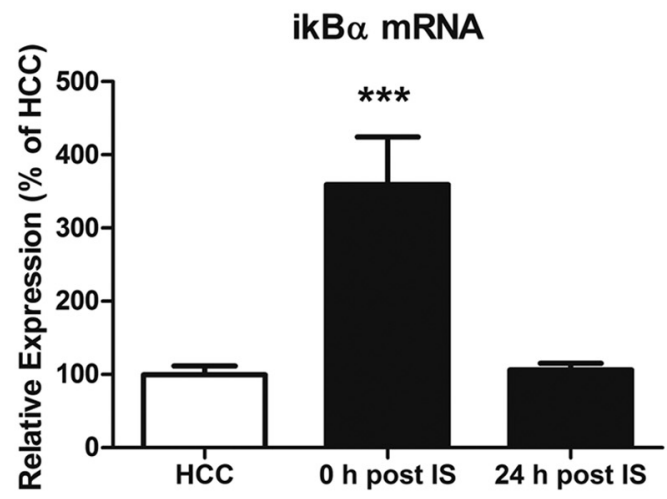

D

active NF-kb Protein

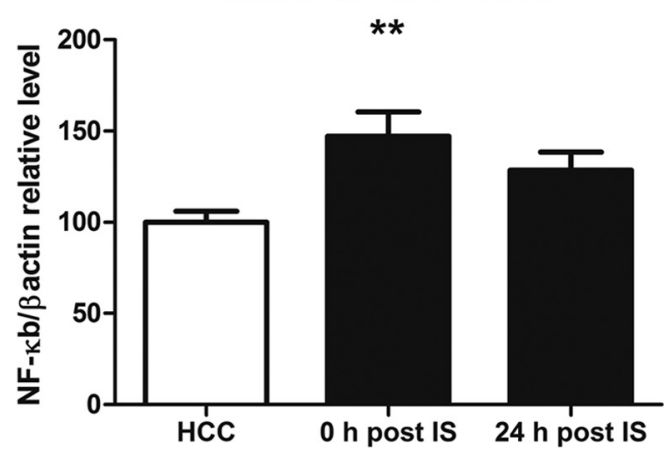

Active NF-KB

$\beta$-actin

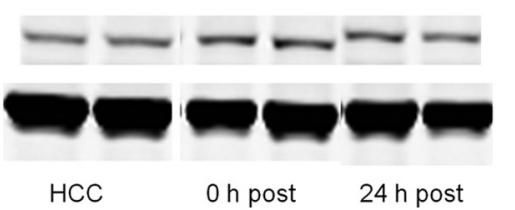

Figure 2. Effect of IS on hippocampal NLRP3 and NF- $\kappa$ B. $A$, NLRP3 mRNA is not changed 0 and $24 \mathrm{~h}$ after IS compared with HCCs. $B, I \kappa B \alpha$ is increased $0 \mathrm{~h}$, but not $24 \mathrm{~h}$, after IS. C, NLRP3 protein is increased 0 and $24 \mathrm{~h}$ after IS compared with HCCS. D. Active NF- $\kappa$ B protein is increased $0 \mathrm{~h}$, but not $24 \mathrm{~h}$, after IS compared with HCCs. The graphs show mean and SEM. Representative Western blots are shown below each graph. $n=8$ per group. ${ }^{*} p<0.05,{ }^{* *} p<0.01,{ }^{* * *} p<0.001$ versus the $\mathrm{HCC}$ group. 
exposure increased activated NF- $\kappa \mathrm{B}$ at $0 \mathrm{~h}\left(F_{(2,23)}=5.537, p<\right.$ 0.01 ) but not $24 \mathrm{~h}$ after stress treatment (Fig. $2 D)$. Similarly, I $\kappa \mathrm{B} \alpha$ gene expression was increased $0 \mathrm{~h}\left(F_{(2,23)}=12.79, p<0.001\right)$ but not $24 \mathrm{~h}$ after stress exposure (Fig. $2 B$ ).

\section{The HMGB-1 antagonist BoxA prevents stress-induced sensitization of the microglial proinflammatory response to LPS ex vivo}

If HMGB-1 signaling is critical to the mediation of IS-induced microglial priming, then blocking HMGB-1 signaling during stress exposure should prevent subsequent stress-induced sensitization of the microglial proinflammatory response. HMGB-1 has three major protein domains consisting of two tandem DNA binding domains (BoxA and BoxB) and an acidic $\mathrm{C}$ terminus. The BoxB domain is critical for the proinflammatory actions of HMGB-1 (Li et al., 2003). The BoxA fragment will bind to receptors but does not initiate proinflammatory actions. However, BoxA occupancy of TLRs will keep HMGB-1 from binding and acts as a competitive antagonist to HMGB-1, displacing radiolabeled HMGB-1 from receptors on macrophages without any intrinsic inflammatory activity (Yang et al., 2004). It is highly selective in that it is the binding fragment of HMGB-1 and so binds only where HMGB-1 would bind. BoxA (10 $\mu \mathrm{g})$ was injected ICM before IS or control treatment. Hippocampal microglia were isolated $24 \mathrm{~h}$ later and stimulated with LPS ex vivo. To determine whether BoxA blocked stress-induced sensitization of the microglia proinflammatory response, area under the curve (AUC) for LPS concentration was computed for each subject to reflect the cumulative proinflammatory response to LPS. IS significantly potentiated interleukin- $1 \beta$ (IL-1 $\beta$ ) gene expression to LPS, which was blocked by BoxA (interaction between IS vs HCC and vehicle vs BoxA, $F_{(1,20)}=6.142, p<0.05$; Fig. $\left.3 A\right)$. A similar interaction was observed with $\mathrm{I} \kappa \mathrm{B} \alpha\left(F_{(1,20)}=4.839, p<0.05\right.$; Fig. $3 B$ ). In addition, IS significantly potentiated NLRP3 gene expression to LPS, which was blocked by BoxA treatment (interaction between IS vs HCC and vehicle vs $\operatorname{BoxA}, F_{(1,20)}=4.094$, $p<0.05$; Fig. 3C). To verify that BoxA is not a general TLR2/4 antagonist but acts selectively against HMGB-1, naive hippocampal microglia were incubated with $2 \mu \mathrm{g} / \mathrm{ml}$ BoxA and $100 \mathrm{ng} / \mathrm{ml}$ LPS (TLR4 agonist) or $100 \mathrm{ng} / \mathrm{ml}$ Pam3CysSerLys4 (TLR2 agonist) for $4 \mathrm{~h}$. IL-1 $\beta$ gene expression was measured as an indicator of the microglial inflammatory response to each TLR agonist. Both LPS and Pam 3 csk 4 increased IL- $1 \beta$ expression, as would be expected, and BoxA did not at all reduce this increase (Fig. $3 D, E$ ).

\section{ICM administration of disulfide HMGB-1, but not fully reduced HMGB-1, primes the proinflammatory response of microglia to LPS ex vivo}

To further examine whether HMGB-1 primes proinflammatory neuroimmune responses and acts in the brain as it does in the periphery, recombinant disulfide or fully reduced HMGB-1 was injected ICM, and the proinflammatory response of hippocampal microglia to LPS was assessed $24 \mathrm{~h}$ after injection. Disulfide HMGB-1 significantly modulated the microglia proinflammatory response to LPS ex vivo for IL- $1 \beta$ (interaction between vehicle and disulfide HMGB-1 vs LPS dose, $F_{(4,30)}=6.933, p<$ $0.001)$, IL-6 $\left(F_{(4,30)}=4.984, p<0.01\right)$, tumor necrosis factor- $\alpha$ $32\left(\mathrm{TNF} \alpha ; F_{(4,30)}=6.970, p<0.001\right), \mathrm{I} \kappa \mathrm{B} \alpha\left(F_{(4,30)}=2.994, p<\right.$ $0.05)$, and NLRP3 $\left(F_{(4,30)}=7.461, p<0.001\right)$ gene expression (Fig. 4). Post hoc analysis showed that disulfide HMGB-1 potentiated the proinflammatory response of IL- $1 \beta(10 \mathrm{ng} / \mathrm{ml} \mathrm{LPS}, p<$ $0.01 ; 100 \mathrm{ng} / \mathrm{ml}, p<0.0001)$, IL-6 (100 ng/ml LPS, $p<0.001)$, TNF $\alpha$ (10 ng/ml LPS, $p<0.05 ; 100 \mathrm{ng} / \mathrm{ml}, p<0.0001), \mathrm{I} \kappa \mathrm{B} \alpha$
(100 ng/ml LPS, $p<0.01)$, and NLRP3 (100 ng/ml, $p<0.0001)$ compared with vehicle-treated rats. The AUC was computed for each subject to compare the cumulative LPS proinflammatory response between HMGB-1- and vehicle-treated rats. Administration of disulfide HMGB-1 resulted in a significant increase in AUC for IL-1 $\beta\left(t_{(6)}=5.568, p<0.01\right)$, IL-6 $\left(t_{(6)}=2.618, p<\right.$ $0.05), \mathrm{TNF} \alpha\left(t_{(6)}=3.032, p<0.05\right), \mathrm{I} \kappa \mathrm{B} \alpha\left(t_{(6)}=2.734, p<\right.$ $0.05)$, and NLRP3 $\left(t_{(6)}=2.967, p<0.05\right)$. In contrast, fully reduced HMGB-1 failed to significantly affect the proinflammatory response of microglia to LPS for IL-1 $\beta$ ( $p=0.80)$, IL-6 ( $p=$ $0.75), \mathrm{TNF} \alpha(p=0.87), \mathrm{I} \kappa \mathrm{B} \alpha(p=0.77)$, or NLRP3 $(p=0.62)$ compared with vehicle-treated rats (Fig. 5).

\section{Discussion}

The present experiments provide the first evidence that exposure to a stressor modulates the alarmin/DAMP HMGB-1 in the CNS and that HMGB-1 primes microglia and amplifies subsequent neuroinflammatory responses. Here, an acute stressor increased HMGB-1 in the hippocampus, an increase still present $24 \mathrm{~h}$ later. HMGB-1 can be released via two distinct mechanisms. The first can yield release from any cell type undergoing non-apoptotic death. The second has been characterized primarily in innate immune cells and involves secretory processes in the absence of cell death (Lotze and Tracey, 2005; Klune et al., 2008). Because microglia are the predominant innate immune cells in the CNS, we examined whether stress induces microglia to actively secrete HMGB-1. Consistent with the effects of stress on hippocampal HMGB-1 in vivo, hippocampal microglia were found to release HMGB-1 ex vivo after stress exposure. It is important that microglia cell viability did not differ between stress and non-stress groups, suggesting that stress induces microglia to actively secrete HMGB-1, a previously unknown phenomenon. However, the present results do not exclude the possibility that other CNS cells produce HMGB-1 in response to stress (Qiu et al., 2008).

Extracellular HMGB-1 acts via RAGE to signal immune cell migration and TLR2/TLR4 to induce proinflammatory mediators (Park et al., 2004). We demonstrated previously that CNS blockade of TLR2 and TLR4 during IS prevents stress-induced priming of the microglial proinflammatory response (Weber et al., 2013). This finding suggested that stress induces the release of an endogenous ligand in CNS, which primes microglia through TLRs. Therefore, we sought to examine the role of HMGB-1 during and after stress. To do so, we used the HMGB-1 antagonist BoxA. BoxA was administered ICM before stress exposure, and hippocampal microglia were isolated $24 \mathrm{~h}$ later to characterize their response to LPS ex vivo. Microglia incubated in media alone expressed low levels of inflammatory genes, regardless of stress or BoxA treatment. However, IS potentiated the proinflammatory response to LPS, an effect that was blocked by BoxA. That is, BoxA prevented microglia from becoming sensitized and supports the ex vivo finding that IS induces the release of HMGB-1 from microglia. The half-life of BoxA is unknown, so a potential confounding factor is that BoxA could be present at microglia and act as a general TLR2 and TLR4 antagonist, thereby blocking the ability of LPS to stimulate proinflammatory cytokines. However, this possibility is unlikely because BoxA did not have any tendency to reduce the inflammatory effect of the TLR2 agonist Pam3csk4 or the TLR4 agonist LPS on microglia in vitro, supporting the contention that BoxA is specifically an HMGB-1 antagonist.

As noted, HMGB-1 in the periphery can have different functions depending on the redox states at three cysteine sites that dictate receptor interaction and proinflammatory activity. Im- 
A

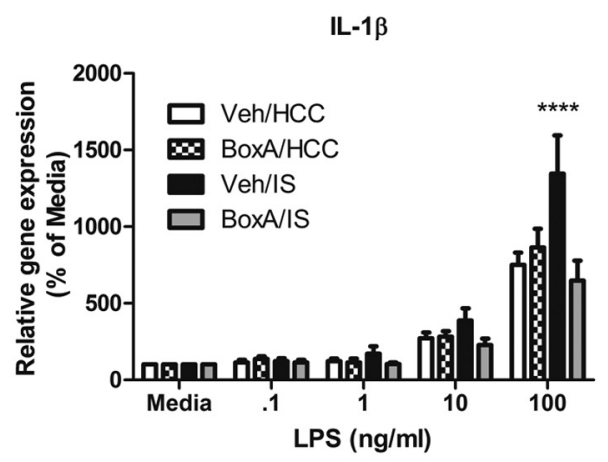

B

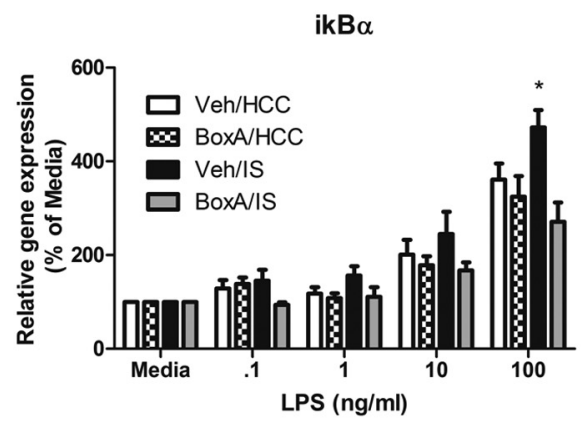

C

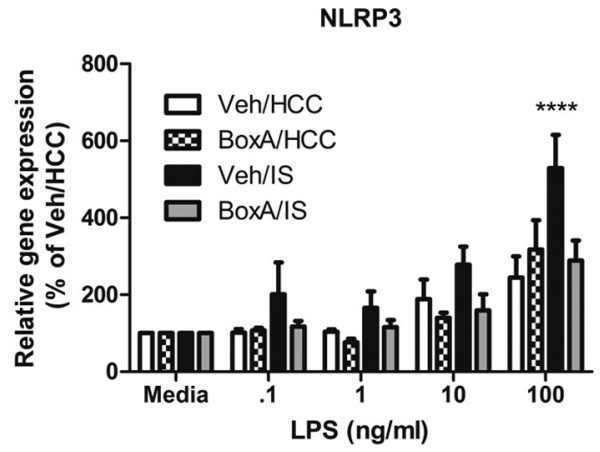

D

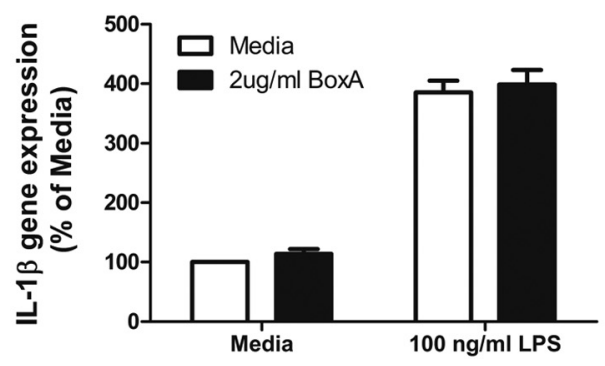

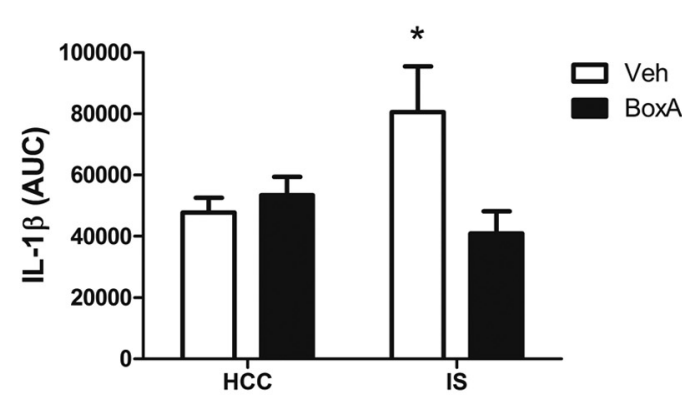
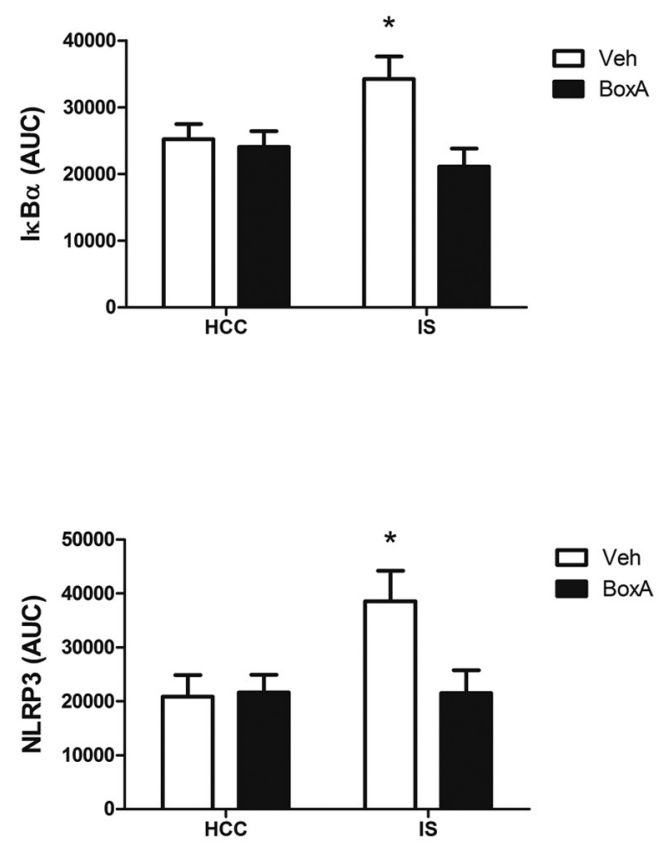

E

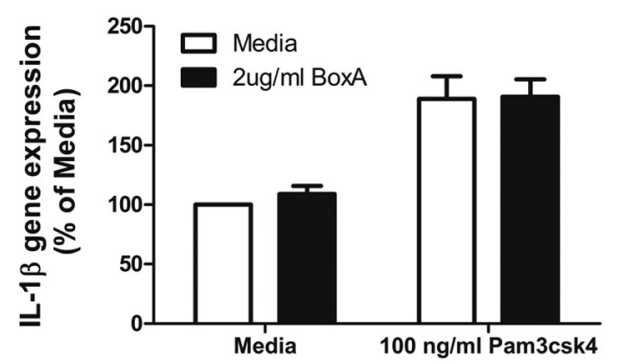

Figure 3. Effect of the HMGB-1 antagonist BoxA on IS-induced priming of microglia to LPS ex vivo. A-C, BoxA (10 $\mu \mathrm{g})$ or vehicle was injected ICM before IS or in HCCs. At $24 \mathrm{~h}$ after stress treatment, microglia were isolated from the hippocampus and challenged with $L P S(0,0.1,1,10$, and $100 \mathrm{ng} / \mathrm{ml})$ for $4 \mathrm{~h}$, and microglial proinflammatory gene expression was measured. To determine whether BoxA blunted stress-induced sensitization of the microglial proinflammatory response, the AUC for LPS concentration was computed for each rat, and the means were compared. $n=6$ per group. BoxA treatment blocked the IS-induced sensitized microglial IL-1 $\beta(\boldsymbol{A}), I_{\kappa} B \alpha(\boldsymbol{B})$, and NLRP3 ( () response to LPS. The graphs show mean and SEM. ${ }^{*} p<0.05$ versus non-asterisk groups. $\boldsymbol{D}, \boldsymbol{E}$, To determine whether BoxA interferes with the ability of TLR2/4 to recognize other agonists, isolated microglia were treated with BoxA ( $2 \mu \mathrm{g} / \mathrm{ml}$ ) or media, and the TLR4-specific antagonist LPS (100 $\mathrm{ng} / \mathrm{ml} ; \boldsymbol{D})$ or the TLR2-specific antagonist Pam3csk4 $(100 \mathrm{ng} / \mathrm{ml} ; \boldsymbol{E})$ for $4 \mathrm{~h}$. IL-1 $\beta$ gene expression was measured as an indicator of the microglial proinflammatory response. $n=4$ per group.

portantly, neither the HMGB-1 antibody used in the present study, nor most others, distinguishes between these different forms, and therefore it is unknown which form of HMGB-1 is released in the CNS.

Whether these different HMGB-1 forms might have different effects in the CNS has not been explored previously. To deter- mine which form primes microglia, disulfide or fully reduced HMGB-1 was administered ICM, and microglia proinflammatory responses to LPS were measured ex vivo $24 \mathrm{~h}$ later. Similar to the effects of stress exposure, microglia incubated in media alone expressed the same level of inflammatory cytokines, regardless of HMGB-1 treatment. Previous reports show that disulfide 
A

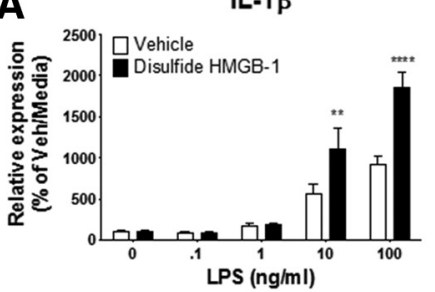

B

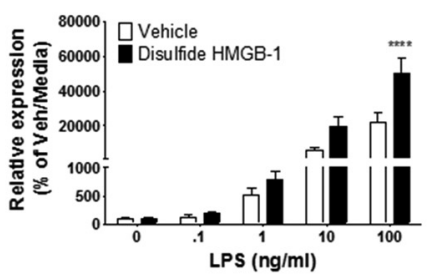

C

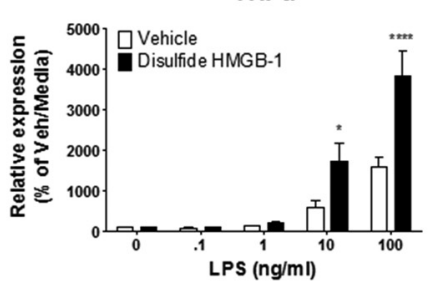

D
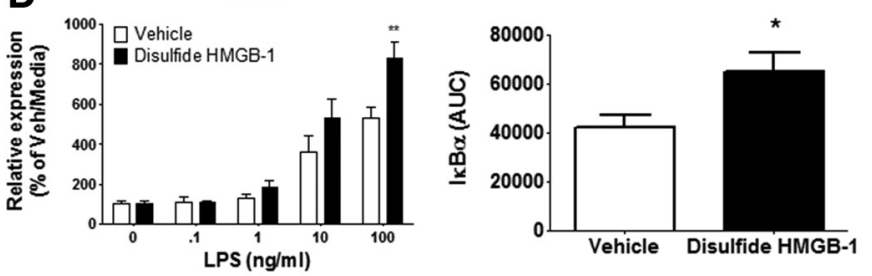

E
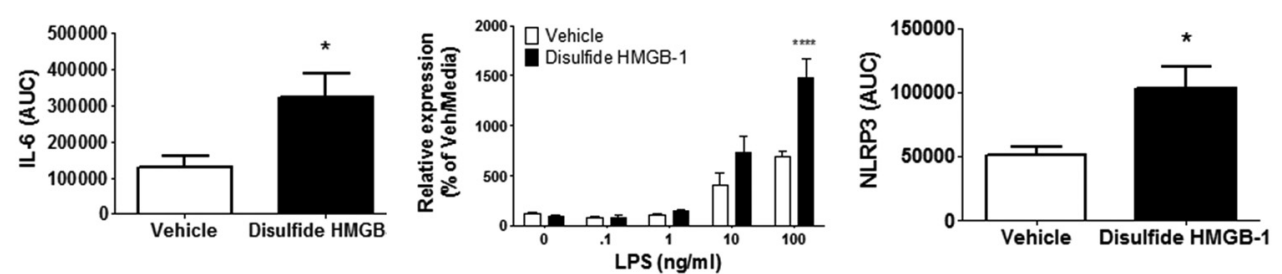

Figure 4. Effect of disulfide HMGB-1 on hippocampal microglia proinflammatory to LPS ex vivo. Disulfide HMGB-1 (1 $\mu \mathrm{g} / 10 \mu \mathrm{l})$ or vehicle was injected ICM. Hippocampal microglia were isolated $24 \mathrm{~h}$ after treatment and stimulated with $\operatorname{LSS}(0,0.1,1,10$, and $100 \mathrm{ng} / \mathrm{ml})$ for $4 \mathrm{~h}$, and proinflammatory gene expression was measured. Relative mRNA expression to the vehicle/media group is shown for IL-1 $\beta(\boldsymbol{A})$, IL-6(B), TNF $\alpha(\boldsymbol{C})$, I $\kappa \mathrm{B} \alpha(\boldsymbol{D})$, and NLRP3 $(\boldsymbol{E})$. Data are presented as mean and SEM, $n=4$ per group. ${ }^{*} p<0.05,{ }^{* *} p<0.01,{ }^{* * *} p<0.001,{ }^{* * * *} p<0.0001$ versus the vehicle group with same LPS concentration; AUC was also calculated and presented as mean and SEM. ${ }^{*} p<0.05,{ }^{* *} p<0.01$ versus the vehicle group.

$$
\text { A } \quad \mathrm{LL}-1 \beta
$$

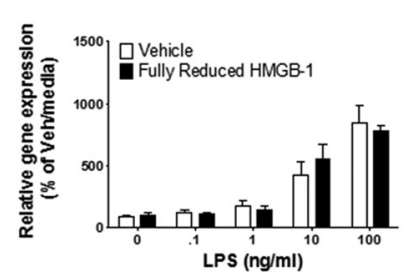

B

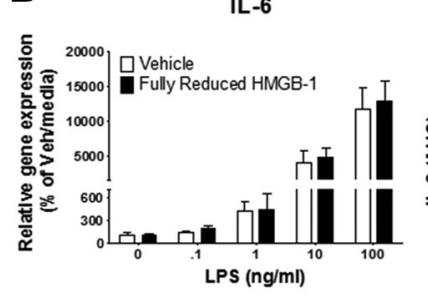

C

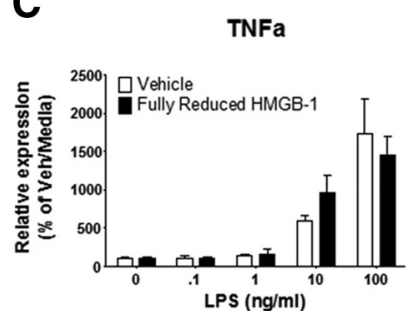

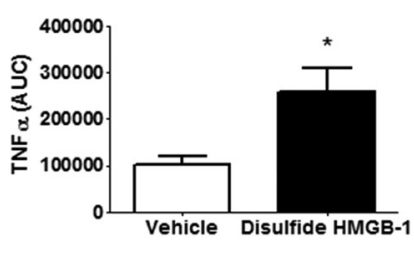

$\mathbf{i k B} \alpha$
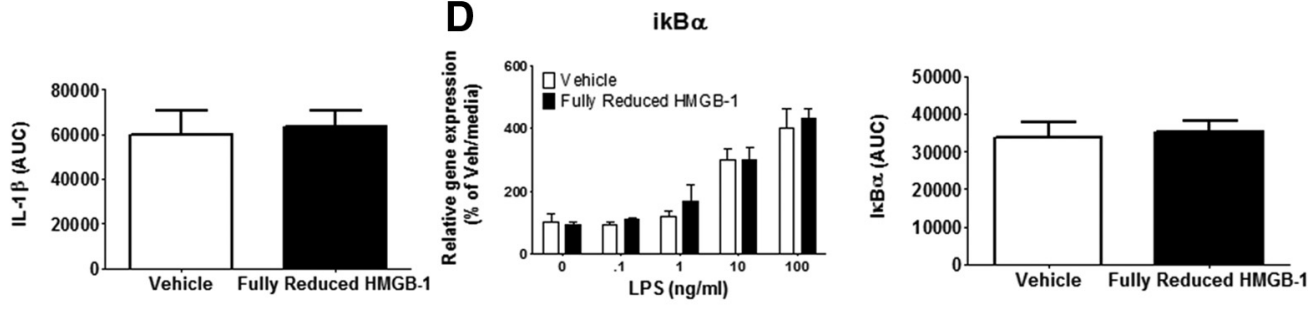

E
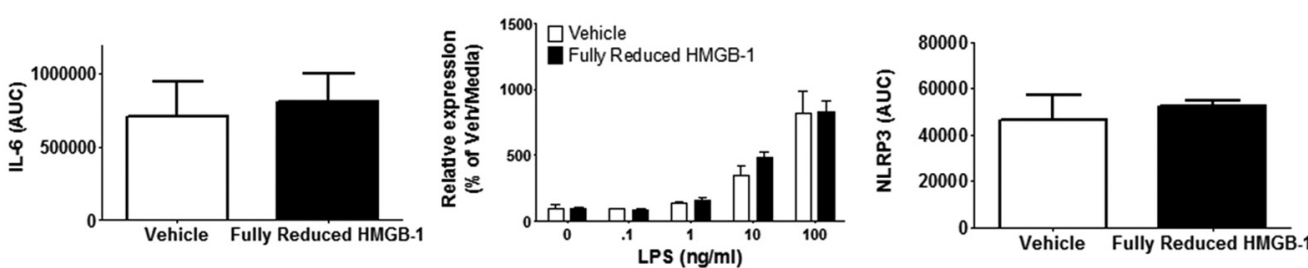

Figure 5. Effect of fully reduced HMGB-1 on hippocampal microglia proinflammatory to LPS ex vivo. Fully reduced HMGB-1 $(1 \mu \mathrm{g} / 10 \mu \mathrm{l})$ or vehicle was injected ICM. Hippocampal microglia were isolated $24 \mathrm{~h}$ after treatment and stimulated with LPS $(0,0.1,1,10$, and $100 \mathrm{ng} / \mathrm{ml})$ for $4 \mathrm{~h}$, and proinflammatory gene expression was measured. Relative mRNA expression to the vehicle/media group is shown for IL-1 $\beta(\boldsymbol{A}), \mathrm{LL}-6(\boldsymbol{B}), \operatorname{TNF} \alpha(\boldsymbol{C}), \mathrm{I} \boldsymbol{\kappa} \boldsymbol{\alpha}(\boldsymbol{D})$, and NLRP3 $(\boldsymbol{E})$. Data are presented as mean and SEM, $n=4$ per group. The AUC was also calculated and presented as mean and SEM. 
HMGB-1 is sufficient to stimulate proinflammatory cytokines (Scaffidi et al., 2002; Park et al., 2004; Agalave et al., 2014). However, disulfide HMGB-1 failed to increase basal levels of proinflammatory cytokine expression here. One possibility is that the proinflammatory cytokine effect of disulfide HMGB-1 had dissipated by $24 \mathrm{~h}$ after treatment. However, other reports suggest that HMGB-1 does not always induce proinflammatory cytokines (Rouhiainen et al., 2007; Sha et al., 2008; Cassetta et al., 2009). Additional studies are needed to measure the inflammatory properties of each redox form closer to the time of injection. Interestingly, microglia isolated from disulfide HMGB-1-treated, but not fully reduced HMGB-1-treated, rats showed a potentiated inflammatory response to LPS. That is, disulfide HMGB-1 was sufficient to prime hippocampal microglia, as does stress. The effects of HMGB-1 on microglial priming are consistent with previous work demonstrating that HMGB-1 is sufficient to prime the inflammatory response of isolated splenocytes (Valdes-Ferrer et al., 2013). It should be noted that stress exposure increases macrophage and monocyte trafficking into the brain (Wohleb et al., 2011, 2013) and microglia density in several stress-reactive brain areas, including the hippocampus (Nair and Bonneau, 2006; Tynan et al., 2010). It is possible that fully reduced HMGB-1 drives this type of trafficking, which could contribute to stress-induced neuroinflammatory responses in vivo. However, the present experiments were designed to target microglial priming specifically, and so the number of microglia were controlled for in the ex vivo environment.

Although the present studies provide evidence that HMGB-1 mediates stress-induced microglial priming, they do not indicate the cellular mechanism by which HMGB-1 does so. We have shown previously that ICM administration of a TLR2/4 antagonist before the stressor blocks stress-induced microglia priming (Weber et al., 2013). Of particular relevance, TLR2 and TLR4 activation can lead to the formation of the NLRP3 inflammasome, a complex that is key to generating IL- $1 \beta$ protein (Hanamsagar et al., 2012). IL-1 $\beta$ is often referred to as the "master regulator" of inflammation because it is a potent signal that stimulates the production of other inflammatory molecules (Basu et al., 2004). NLRP3 is unique among NLR inflammasomes in that assembly and activation of the NLRP3 inflammasome involves a two-step process. First, a priming signal is required to increase NLRP3 protein levels to a critical threshold. A second signal is then required that induces NLRP3 to form a complex with Apoptosis-associated speck-like protein containing a CARD (ASC) and pro-caspase-1. Formation of this complex results in proteolytic cleavage of pro-caspase- 1 to active caspase- 1 , which cleaves pro-IL- $1 \beta$ into the bioactive mature IL- $1 \beta$ (Martinon et al., 2009). Interestingly, HMGB-1 has been found to increase NLRP3 mRNA and protein (Xiang et al., 2011). Indeed, it has been argued that DAMPs, such as HMGB-1, prime the NLRP3 inflammasome and potentiate inflammation (Leemans et al., 2011).

Given the above, it is important that stress exposure increased NLRP3 protein in the hippocampus, an increase still present $24 \mathrm{~h}$ after stressor termination. However, the present IS paradigm does not alter IL- $1 \beta$ protein in the hippocampus $24 \mathrm{~h}$ after stressor termination (Frank et al., 2007), suggesting that the NLRP3 inflammasome is primed but not active. This result is consistent with other findings in which chronic stress increased NLRP3 in the prefrontal cortex (Pan et al., 2014). Unexpectedly, NLRP3 mRNA was not changed here after the stressor. However, the stress paradigm is $\sim 2 \mathrm{~h}$. Therefore, it is possible that NLRP3 mRNA did increase but had returned to basal levels by the end of the stressor. Activation of the transcription factor NF- $\kappa \mathrm{B}$ drives NLRP3 to prime inflammasome formation (Bauernfeind et al., 2009). Importantly, active NF- $\kappa \mathrm{B}$ protein and $\mathrm{I} \kappa \mathrm{B} \alpha$ mRNA, an inhibitor of NF- $\kappa \mathrm{B}$ that is induced after NF- $\kappa \mathrm{B}$ activation, were increased $0 \mathrm{~h}$, but not $24 \mathrm{~h}$, after stress. The finding that microglial NLRP3 mRNA was sensitized to LPS after stress exposure further implicates this pathway in stress-induced neuroinflammatory priming. Interestingly, treatment with BoxA before stress blocked NLRP3 sensitization, suggesting that stress-induced HMGB-1 drives NLRP3 priming. In addition, administration of disulfide HMGB-1, but not fully reduced HMGB-1, sensitized microglia NLRP3 mRNA to LPS. As a body, these data provide initial evidence that stress exposure may prime neuroinflammatory processes via HMGB-1 activating NF- $\kappa \mathrm{B}$ to prime the NLRP3 inflammasome.

The present results encourage the expansion of the role of HMGB-1 into other stress paradigms. Chronic unpredictable stress (Munhoz et al., 2006) and repeated social defeat (Wohleb et al., 2012), for example, increase inflammatory processes to a later immune challenge. Thus, HMGB-1 may function broadly.

Of course, this leaves the question of what CNS signal leads to HMGB-1 increases and release from microglia. Because blocking TLR2 and TLR4 during IS prevented stress-induced microglial priming (Weber et al., 2013), one possibility is that an unknown ligand, signaling at TLR2 and/or TLR4, initiates HMGB-1 release from microglia. Another possibility involves glucocorticoids as critical mediators. Previous studies show that glucocorticoids, and glucocorticoid receptor signaling in particular, are necessary and sufficient to prime microglia (Frank et al., 2010). This is an active topic of investigation.

Although the purpose of the present studies was to explore mechanisms by which stressors sensitize neuroinflammatory responses to subsequent immune challenges, they also comment more generally on the role of DAMPs, such as HMGB-1, at least in the brain. When it was first argued that immune cells respond to "danger signals," the term danger was used quite loosely. However, as a recent review of this concept by Pradeu and Cooper (2012) makes clear, by danger, immunologists meant damage to cells or tissues. Although we cannot dissociate between the physical and psychological effect of the stressor, the present results suggest consideration of the idea that, perhaps, DAMPs respond to external threats as well as cellular damage.

\section{References}

Agalave NM, Larsson M, Abdelmoaty S, Su J, Baharpoor A, Lundback P, Palmblad K, Andersson U, Harris H, Svensson CI (2014) Spinal HMGB1 induces TLR4-mediated long-lasting hypersensitivity and glial activation and regulates pain-like behavior in experimental arthritis. Pain 155:1802-1813. CrossRef Medline

Altschul SF, Madden TL, Schaffer AA, Zhang J, Zhang Z, Miller W, Lipman DJ (1997) Gapped BLAST and PSI-BLAST: a new generation of protein database search programs. Nucleic Acids Res 25:3389-3402. CrossRef Medline

Basu A, Krady JK, Levison SW (2004) Interleukin-1: a master regulator of neuroinflammation. J Neurosci Res 78:151-156. CrossRef Medline

Bauernfeind FG, Horvath G, Stutz A, Alnemri ES, MacDonald K, Speert D, Fernandes-Alnemri T, Wu J, Monks BG, Fitzgerald KA, Hornung V, Latz E (2009) Cutting edge: NF-kappaB activating pattern recognition and cytokine receptors license NLRP3 inflammasome activation by regulating NLRP3 expression. J Immunol 183:787-791. CrossRef Medline

Bianchi ME (2007) DAMPs, PAMPs and alarmins: all we need to know about danger. J Leukoc Biol 81:1-5. CrossRef Medline

Cassetta L, Fortunato O, Adduce L, Rizzi C, Hering J, Rovere-Querini P, Bianchi ME, Alfano M, Poli G (2009) Extracellular high mobility group box-1 inhibits R5 and X4 HIV-1 strains replication in mononuclear 
phagocytes without induction of chemokines and cytokines. Aids 23:567577. CrossRef Medline

de Pablos RM, Villaran RF, Arguelles S, Herrera AJ, Venero JL, Ayala A, Cano J, Machado A (2006) Stress increases vulnerability to inflammation in the rat prefrontal cortex. J Neurosci 26:5709-5719. CrossRef Medline

Espinosa-Oliva AM, de Pablos RM, Villaran RF, Arguelles S, Venero JL, Machado A, Cano J (2011) Stress is critical for LPS-induced activation of microglia and damage in the rat hippocampus. Neurobiol Aging 32:85102. CrossRef Medline

Fillman SG, Sinclair D, Fung SJ, Webster MJ, Shannon Weickert C (2014) Markers of inflammation and stress distinguish subsets of individuals with schizophrenia and bipolar disorder. Transl Psychiatry 4:e365. CrossRef Medline

Frank MG, Wieseler-Frank JL, Watkins LR, Maier SF (2006) Rapid isolation of highly enriched and quiescent microglia from adult rat hippocampus: Immunophenotypic and functional characteristics. J Neurosci Methods 151:121-130. CrossRef Medline

Frank MG, Baratta MV, Sprunger DB, Watkins LR, Maier SF (2007) Microglia serve as a neuroimmune substrate for stress-induced potentiation of CNS pro-inflammatory cytokine responses. Brain Behav Immun 21:47-59. CrossRef Medline

Frank MG, Miguel ZD, Watkins LR, Maier SF (2010) Prior exposure to glucocorticoids sensitizes the neuroinflammatory and peripheral inflammatory responses to E. coli lipopolysaccharide. Brain Behav Immun 24: 19-30. CrossRef Medline

Gadek-Michalska A, Tadeusz J, Rachwalska P, Bugajski J (2013) Cytokines, prostaglandins and nitric oxide in the regulation of stress-response systems. Pharmacol Rep 65:1655-1662. CrossRef Medline

Hanamsagar R, Hanke ML, Kielian T (2012) Toll-like receptor (TLR) and inflammasome actions in the central nervous system. Trends Immunol 33:333-342. CrossRef Medline

Holguin A, Frank MG, Biedenkapp JC, Nelson K, Lippert D, Watkins LR, Rudy JW, Maier SF (2007) Characterization of the temporo-spatial effects of chronic bilateral intrahippocampal cannulae on interleukin1beta. J Neurosci Methods 161:265-272. CrossRef Medline

Johnson JD, O'Connor KA, Deak T, Stark M, Watkins LR, Maier SF (2002) Prior stressor exposure sensitizes LPS-induced cytokine production. Brain Behav Immun 16:461-476. CrossRef Medline

Kang R, Chen R, Zhang Q, Hou W, Wu S, Cao L, Huang J, Yu Y, Fan XG, Yan Z, Sun X, Wang H, Wang Q, Tsung A, Billiar TR, Zeh HJ 3rd, Lotze MT, Tang D (2014) HMGB1 in health and disease. Mol Aspects Med. Advance online publication. Retrieved November 12, 2014. doi:10.1016/ j.mam.2014.05.001 CrossRef Medline

Klune JR, Dhupar R, Cardinal J, Billiar TR, Tsung A (2008) HMGB1: endogenous danger signaling. Mol Med 14:476-484. CrossRef Medline

Leemans JC, Cassel SL, Sutterwala FS (2011) Sensing damage by the NLRP3 inflammasome. Immunol Rev 243:152-162. CrossRef Medline

Li J, Kokkola R, Tabibzadeh S, Yang R, Ochani M, Qiang X, Harris HE, Czura CJ, Wang H, Ulloa L, Warren HS, Moldawer LL, Fink MP, Andersson U, Tracey KJ, Yang H (2003) Structural basis for the proinflammatory cytokine activity of high mobility group box 1 . Mol Med 9:37-45. Medline

Lotze MT, Tracey KJ (2005) High-mobility group box 1 protein (HMGB): nuclear weapon in the immune arsenal. Nat Rev Immunol 5:331-342. CrossRef Medline

Martinon F, Mayor A, Tschopp J (2009) The inflammasomes: guardians of the body. Annu Rev Immunol 27:229-265. CrossRef Medline

Matzinger P (2002) The danger model: a renewed sense of self. Science 296: 301-305. CrossRef Medline

Munhoz CD, Lepsch LB, Kawamoto EM, Malta MB, Lima Lde S, Avellar MC, Sapolsky RM, Scavone C (2006) Chronic unpredictable stress exacerbates lipopolysaccharide-induced activation of nuclear factor- $\kappa \mathrm{B}$ in the frontal cortex and hippocampus via glucocorticoid secretion. J Neurosci 26:3813-3820. CrossRef Medline

Nair A, Bonneau RH (2006) Stress-induced elevation of glucocorticoids increases microglia proliferation through NMDA receptor activation. J Neuroimmunol 171:72-85. CrossRef Medline

Pan Y, Chen XY, Zhang QY, Kong LD (2014) Microglial NLRP3 inflammasome activation mediates IL-1beta-related inflammation in prefrontal cortex of depressive rats. Brain Behav Immun 41:90-100. CrossRef Medline

Park JS, Svetkauskaite D, He Q, Kim JY, Strassheim D, Ishizaka A, Abraham E
(2004) Involvement of toll-like receptors 2 and 4 in cellular activation by high mobility group box 1 protein. J Biol Chem 279:7370-7377. CrossRef Medline

Pradeu T, Cooper EL (2012) The danger theory: 20 years later. Front Immunol 3:287. CrossRef Medline

Qiu J, Nishimura M, Wang Y, Sims JR, Qiu S, Savitz SI, Salomone S, Moskowitz MA (2008) Early release of HMGB-1 from neurons after the onset of brain ischemia. J Cereb Blood Flow Metab 28:927-938. CrossRef Medline

Rouhiainen A, Tumova S, Valmu L, Kalkkinen N, Rauvala H (2007) Pivotal advance: analysis of proinflammatory activity of highly purified eukaryotic recombinant HMGB1 (amphoterin). J Leukoc Biol 81:49-58. CrossRef Medline

Scaffidi P, Misteli T, Bianchi ME (2002) Release of chromatin protein HMGB1 by necrotic cells triggers inflammation. Nature 418:191-195. CrossRef Medline

Sha Y, Zmijewski J, Xu Z, Abraham E (2008) HMGB1 develops enhanced proinflammatory activity by binding to cytokines. J Immunol 180:25312537. CrossRef Medline

Tynan RJ, Naicker S, Hinwood M, Nalivaiko E, Buller KM, Pow DV, Day TA, Walker FR (2010) Chronic stress alters the density and morphology of microglia in a subset of stress-responsive brain regions. Brain Behav Immun 24:1058-1068. CrossRef Medline

Valdes-Ferrer SI, Rosas-Ballina M, Olofsson PS, Lu B, Dancho ME, Li JH, Yang H, Pavlov VA, Chavan SS, Tracey KJ (2013) High-mobility group box 1 mediates persistent splenocyte priming in sepsis survivors: evidence from a murine model. Shock 40:492-495. CrossRef Medline

van Zoelen MA, Yang H, Florquin S, Meijers JC, Akira S, Arnold B, Nawroth PP, Bierhaus A, Tracey KJ, van der Poll T (2009) Role of toll-like receptors 2 and 4, and the receptor for advanced glycation end products in high-mobility group box 1-induced inflammation in vivo. Shock 31:280284. CrossRef Medline

Venereau E, Casalgrandi M, Schiraldi M, Antoine DJ, Cattaneo A, De Marchis F, Liu J, Antonelli A, Preti A, Raeli L, Shams SS, Yang H, Varani L, Andersson U, Tracey KJ, Bachi A, Uguccioni M, Bianchi ME (2012) Mutually exclusive redox forms of HMGB1 promote cell recruitment or proinflammatory cytokine release. J Exp Med 209:1519-1528. CrossRef Medline

Venereau E, Schiraldi M, Uguccioni M, Bianchi ME (2013) HMGB1 and leukocyte migration during trauma and sterile inflammation. Mol Immunol 55:76-82. CrossRef Medline

Weber MD, Frank MG, Sobesky JL, Watkins LR, Maier SF (2013) Blocking toll-like receptor 2 and 4 signaling during a stressor prevents stressinduced priming of neuroinflammatory responses to a subsequent immune challenge. Brain Behav Immun 32:112-121. CrossRef Medline

Wohleb ES, Hanke ML, Corona AW, Powell ND, Stiner LM, Bailey MT, Nelson RJ, Godbout JP, Sheridan JF (2011) $\beta$-Adrenergic receptor antagonism prevents anxiety-like behavior and microglial reactivity induced by repeated social defeat. J Neurosci 31:6277-6288. CrossRef Medline

Wohleb ES, Fenn AM, Pacenta AM, Powell ND, Sheridan JF, Godbout JP (2012) Peripheral innate immune challenge exaggerated microglia activation, increased the number of inflammatory CNS macrophages, and prolonged social withdrawal in socially defeated mice. Psychoneuroendocrinology 37:1491-1505. CrossRef Medline

Wohleb ES, Powell ND, Godbout JP, Sheridan JF (2013) Stress-induced recruitment of bone marrow-derived monocytes to the brain promotes anxiety-like behavior. J Neurosci 33:13820-13833. CrossRef Medline

Xiang M, Shi X, Li Y, Xu J, Yin L, Xiao G, Scott MJ, Billiar TR, Wilson MA, Fan J (2011) Hemorrhagic shock activation of NLRP3 inflammasome in lung endothelial cells. J Immunol 187:4809-4817. CrossRef Medline

Yang H, Tracey KJ (2009) Targeting HMGB1 in inflammation. Biochim Biophys Acta 1799:149-156. CrossRef Medline

Yang H, Ochani M, Li J, Qiang X, Tanovic M, Harris HE, Susarla SM, Ulloa L, Wang H, DiRaimo R, Czura CJ, Roth J, Warren HS, Fink MP, Fenton MJ, Andersson U, Tracey KJ (2004) Reversing established sepsis with antagonists of endogenous high-mobility group box 1. Proc Natl Acad Sci U S A 101:296-301. CrossRef Medline

Yang H, Lundback P, Ottosson L, Erlandsson-Harris H, Venereau E, Bianchi ME, Al-Abed Y, Andersson U, Tracey KJ, Antoine DJ (2012) Redox modification of cysteine residues regulates the cytokine activity of high mobility group box-1 (HMGB1). Mol Med 18:250-259. CrossRef Medline 